\title{
EFFECT OF PEER-LED AND PARENT-LED EDUCATION INTERVENTIONS ON MENSTRUAL HYGIENE-RELATED KNOWLEDGE OF IN-SCHOOL ADOLESCENT GIRLS IN OGUN STATE, NIGERIA
}

\section{Ugochinyere Chinasa Ekeanyanwu* and Catherine Olukemi Agbede}

Department of Public Health, Babcock University, ilishan Remo, Ogun State, Nigeria.

*E-mail: ugochiekeanyanwu@ rocketmail.com

Cite this article:

Ugochinyere C.E., Catherine O.A. (2021), Effect of PeerLed and Parent-Led Education Interventions on Menstrual Hygiene-Related Knowledge of In-School Adolescent Girls in Ogun State, Nigeria. International Journal of Public Health and Pharmacology 2(1), 1-14. DOI:

10.52589/IJPHP-DJSHA0UN.

\section{Manuscript History}

Received: 12 June 2021

Accepted: 9 July 2021

Published: 26 July 2021

Copyright $\odot 2020$ The Author(s). This is an Open Access article distributed under the terms of Creative Commons AttributionNonCommercial-NoDerivatives 4.0 International (CC BY-NC-ND 4.0), which permits anyone to share, use, reproduce and redistribute in any medium, provided the original author and source are credited.
ABSTRACT: The purposes of the study was to determine the effectiveness of peer-led and parent-led education on menstrual hygiene-related knowledge of in-school adolescent girls in Ogun state, Nigeria, which was conceptualized using the Health Belief Model. The study employed a quasi-experimental design with 120 in-school adolescent girls selected through a multistage sampling technique from four (4) secondary schools within Ogun East. A validated instrument was used for data collection. The findings showed that the adolescent girls' level of menstrual hygiene knowledge had a significant increase after the intervention. The peer-led group better predicted higher knowledge scores (mean diff $=7.13$; effect size $=4.34 ; t=19.091 ; p=0.000)$. In conclusion, the peer-led education intervention was more effective in improving the level of adolescent girls' menstrual hygiene knowledge in Ogun State. It is recommended that peer educators be recruited for future interventions to change the reproductive health behaviors of adolescent girls nationally.

KEYWORDS: Menstrual Hygiene, Adolescent girls, Knowledge, Peer-led, Parent-led, Health Belief Model. 


\section{INTRODUCTION}

The onset of menstruation signifies a milestone in the pubertal development of an adolescent girl. During menstruation, hygiene is an inevitable part of a woman's and a girl's life (Sharma et al., 2019; Coast, Lattof, \& Strong, 2019). Various aspects such as physiology, pathology, and psychology of menstruation are associated with the health and well-being of women and adolescent girls; hence, it is a significant issue regarding morbidity and mortality of the population of females (Deshpande, Patil, Gharai, Patil \& Durgawale, 2018). Poor menstrual hygiene may lead to problems like bad odour, rashes, and itching in the perineal region, complications like pelvic inflammatory diseases, and also can lead to school absenteeism and increased school dropout (Akinwaare, Akindele, \& Oluwatosin, 2016; Goel, Kumar, Meena, \& Garg, 2018).

Globally, adolescent girls have developed their strategies to cope with menstruation and this differs from country to country and with nations (Torondel \& Sumpter, 2013). In low and middle-income countries, especially in the rural areas, they constitute a susceptible group not only regarding their social status but also concerning their health as they experience menstruation unprepared, uninformed, and lack adequate support for understanding and managing it (House, Mahon, \& Cavill, 2012). This may impact their self-esteem, confidence, bodily autonomy, and educational experiences (MacRae, Clasen, Dasmohapatra, \& Caruso, 2019; Rani, Kumari, \& Rani, 2019).

In Nigeria, approximately $52 \%$ of the population of females is of reproductive age, and the issue of menstruation and menstrual hygiene discussed at home as well as at school is not adequate (Busari, 2012; Health for All Initiative [HAFAI], 2019). This issue is observed mostly in a traditional and poorly educated environment as a result of the misconceptions that menstruation is perceived as dirty and shameful (Busari, 2012; Ball, 2017). Due to these misconceptions, adolescent girls may not have adequate information about how to maintain hygiene during their menstrual flow.

According to previous studies especially in the southwest of Nigeria, menstrual hygiene is an issue that is insufficiently acknowledged. For instance, a study of 318 female secondary students in Iragbiji, Osun State reported an inadequate knowledge of personal hygiene during their menstrual flow (Oniyangi \& Oyelami, 2018).

Hence, adolescent girls must be educated on the facts about menstrual hygiene and its physiological and psychological implications. Research has shown that better-educated girls are more likely to be healthier than uneducated girls (Alam et al., 2017). Health education and sensitization at the grassroots level play an essential role in improving the knowledge of adolescent girls (Rakhmilla, Rudibianti, Biben, \& Rosyada, 2017). Also, it has a purpose to encourage and increase awareness of menstrual hygiene in a society as well as in a school environment, to escalate illiteracy in the future (Mudey et al., 2010).

The Health belief model [HBM] was adopted for this study. This is a cognitive model that is used to predict if people can prevent and become aware of a disease or an illness, and this can facilitate resolving problematic behaviours (Huang, Kuo, Wang, Wang, \& Tsai, 2016). The model also assumes that the decisions of people to participate in health-related behaviour are determined by some variables, and one of the variables of this model features the concept of 
knowledge. Knowledge is an individual's storehouse of information about preventive care behaviour.

The purpose of the study was to determine the effectiveness of peer-led and parent-led education on menstrual hygiene-related knowledge of in-school female adolescents in Ogun state, Nigeria. The study postulated that there will be no significant difference in the level of in-school female adolescents' menstrual hygiene knowledge between baseline and 6-weeks follow-up.

\section{METHODS}

\section{Study Design}

The study was a quasi-experimental study comprising three experimental groups and a control group, using a quantitative approach. The study comprised a health education programme based on menstrual hygiene that was delivered to the three experimental groups, and a placebo was delivered to the control group. The intervention took place over 4 weeks in four sessions lasting for an average of 120 minutes. Data were collected before the program and at 4 weeks post-intervention in both the experimental and control groups.

\section{Study Area}

The experimental sites were in Saapade, Itamapako, and Aiyepe Community, while the control site was in Ladugbo. All four communities lie within the local government areas of RemoNorth, Ijebu- Ode, Odogbolu, and Ijebu-North of Ogun State where people are predominantly farmers and traders.

\section{Inclusion and Exclusion Criteria}

Those included were the female students who were between 10-19 years of age and who had attained menarche, selected with the assumption that they were registered students of the school and whose parents gave consent and were willing to participate in the study. Those excluded were the female students who were below and above 10-19 years of age and who had not attained menarche, absent from school on the day of the study, and whose parents did not give consent and were not willing to participate in the study.

\section{Sampling Procedure}

The multistage sampling technique was used in selecting the participants until the desired sample size was reached. Ogun East was purposely selected, and from there, four local government areas were randomly selected through balloting, after which one public secondary school was randomly selected from each of the selected local government areas.

\section{Sample size}

The sample size was derived from the computation using a level of significance of $95 \%$ and $80 \%$ power. There was no given estimate of the prevalence of poor menstrual hygiene in 
secondary school female adolescents in Ogun State. Thus, the sample size was determined using the prevalence at $50 \%$.

$$
\mathrm{n}=\frac{\left(\mathrm{Z}_{\alpha}+\mathrm{Z}_{\beta}\right)^{2} \times \mathrm{P}_{0}\left(1-\mathrm{P}_{0}\right)}{\left(\mathrm{P}_{1}-\mathrm{P}_{0}\right)^{2}}
$$

where $\mathrm{n}$ is the minimum sample size per group

$\mathrm{Z}_{\alpha}=95 \%$ confidence interval i.e 1.96

$Z_{\beta}=80 \%$ i.e 0.84 (power to detect changes in the outcome variable and avoid type II error)

$\mathrm{P}_{0}=$ prevalence $($ at $50 \%)$

$\mathrm{P}_{1}=80 \%$ (desired level of outcome variable)

$\mathrm{n}=\underline{(1.96+0.84)^{2} \times 0.5(1-0.5)}$

$$
(0.8-0.5)^{2}
$$

$\underline{(2.8)^{2} \times 0.5(0.5)}$

$$
(0.8-0.5)^{2}
$$

\section{$\underline{7.84 \times 0.25}$}

0.09

$$
=21.78 \simeq 22
$$

The minimum sample size was $22.10 \%$ was added to the minimum sample size to take care of attrition. The total number of participants after adding $10 \%$ of 22 was $22+2.2=24 \simeq 30$. Based on the computation, a total number of 120 participants ( 30 per group X 4) from the four selected secondary schools was considered for the study (representing 30 people per group).

\section{Instrument for Data Collection}

A quantitative approach which comprised close-ended questions was used for this study. The instrument was a semi-structured and participant-administered questionnaire that sought information on socio-demographic characteristics and menstrual hygiene-related knowledge of in-school female adolescents in selected secondary schools in Ogun State. The same instrument was administered at baseline, immediate post-intervention, and 6-weeks follow-up.

\section{Study Variables}

The peer-led and parent-led education programmes were the independent variables while knowledge on menstrual hygiene was the dependent variable.

\section{Validity and reliability}

Face validity of the instrument was adopted and this was checked by lecturers in the department. Content validity was also adopted by ensuring that the items were carefully and 
thoughtfully prepared to align with variables. It was also ensured that the conceptual framework was appropriate and the variables were selected from the model (HBM).

To ascertain the reliability of the instrument, a pilot test was conducted for internal consistency of the instrument, using $10 \%$ of the anticipated sample size. The instrument was distributed to 10 in-school female adolescents in a community with the same characteristics as the population of the study. The data was statistically analysed using the Cronbach alpha standard score to test its reliability. The reliability score generated was 0.75 .

\section{Data analysis}

The data collected from the study was collated, entered, and coded using the Statistical Package for Social Sciences (SPSS) version 23. Both descriptive and inferential statistics were used for data analysis and a statistical level of significance for the inferential statistics was set at $\mathrm{p}<0.05$.

\section{RESULTS}

One hundred and twenty female adolescents were recruited for the intervention from four secondary schools in four local government areas (LGAs) in Ogun State, Nigeria. The intervention and control groups each had 30 participants at the start of the study. At the postintervention and follow-up points, the intervention and control groups had 100\% response rates.

There were more female students in the middle adolescence (14-16 years) age bracket across the three intervention groups and more adolescents between the ages of 17-19 years in the control group. The mean \pm SD ages of the adolescents at menarche across the four groups were $12.97 \pm 1.47$ years, $13.07 \pm 1.70$ years, $12.07 \pm 1.17$ years, and $12.83 \pm 0.87$ years respectively. The female adolescents were recruited from all secondary school classes except SSS 3. The majority were Christians (Table 1). The ethnic distribution showed that the majority of the female adolescents were from the Yoruba ethnic group. The results also disclosed that across the groups, the majority of the female adolescents' mothers had at least secondary or tertiary education and were businesswomen or traders (Table 2).

Regarding the awareness of menstrual hygiene among the female adolescents in this study, 20 (66.7\%), 21 (70\%), $24(80 \%)$, and $26(86.7 \%)$ were aware and the information was sourced from mothers, teachers, sisters, and relatives (Table 3 ).

\section{Baseline Comparison of the Level of Female Adolescents' Knowledge of Menstrual Hygiene in Control and Intervention Groups}

The section assessed the level of menstrual hygiene knowledge of in-school female adolescents. The menstrual hygiene knowledge computed on a 17-point rating scale had mean scores of $8.13 \pm 2.474,8.70 \pm 2.103,9.93 \pm 2.333$, and $8.97 \pm 2.266$ in the parent-led, peer-led, parent and peer-led, and control groups respectively (Table 4). The levels increased after the intervention and were maintained through the follow-up period; unlike the three (3) intervention groups, the control group did not have a significant change in the level of knowledge (Table 5). 


\section{Change in level of Knowledge from Baseline to 6-weeks follow-up}

The level of knowledge of the female adolescents in the parent-led, peer-led, parent, and peerled had an increase of 6.87, 7.13, and 6.47 in the mean between the baseline and 6-week follow-up $(p=0.000)$. The change in the level of knowledge among participants in the peerled group was maximal at 7.13 This change was however statistically significant. In the control group, the mean difference was 0.20 between the desired periods (Table 6).

\section{Research Hypothesis}

There will be no significant difference in the level of in-school female adolescents' menstrual hygiene knowledge between baseline and 6-weeks follow-up. A paired T-test analysis was conducted in determining the results. The findings revealed that the observed difference in mean the parent-led group $(\Delta=6.87 ; \mathrm{t}=9.819 ; p=0.000)$, peer-led group $(\Delta=7.13 ; \mathrm{t}=19.091$; $p=0.000)$, and combination of parent and peer-led group intervention group $(\Delta=6.47 ; \mathrm{t}=$ $12.647 ; p=0.000$ ) were statistically significant (Table 6).

The results show that the educational interventions administered to the three groups had a significant impact on the menstrual hygiene knowledge of the female adolescents. The null hypothesis is therefore rejected in favour of the alternative hypothesis (Table 6).

\section{DISCUSSION}

The overall mean \pm SD age of the female adolescents recruited into this study was $14.92 \pm 1.82$ years which is similar to the age of high school students reported in the Southwest (Fehintola, Fehintola, Aremu, Idowu, Ogunlaja \& Ogunlaja, 2017) and South-South (Edet, Bassey, Esienuomoh \& Ndep, 2020) but slightly lower than ages as reported by Duru, Ikeanyi and Merenu (2020) in the Southeastern part of Nigeria. The mean \pm SD age at menarche of the adolescents in this study was $12.73 \pm 1.38$ years, which is comparable to the mean age reported among girls in the Southwest by Fehintola, Fehintola, Aremu, Idowu, Ogunlaja, and Ogunlaja (2017), in South-South by Duru, Ikeanyi and Merenu (2020) but lower compared to findings by Okafor-Terver and Chuemchit (2017) in the northern part of Nigeria. The disparity in the mean age at menarche can be attributed to socioeconomic and genetic factors as stated by Karapanou and Papadimitriou (2010) and Heidi (1986).

The majority of the adolescents across the four groups in this study reported to have been aware of menstrual hygiene and this finding can be linked to the class and age characteristic. Considering the mean age and the adolescents' class distribution, it was believed that the majority of the participants of this study would have experienced menarche which is the first menstrual bleeding that occurs about two years after the first changes in breast development.

Findings from this study showed that mothers were the adolescents' main source of information regarding menstrual hygiene. Similar results on the role of mothers on the knowledge of young girls regarding menstrual hygiene have been reported by Thakre, Thakre, Reddy, Rathi, Pathak, and Ughade (2013) and Sapkota, Sharma, Budhathoki, Khanal, and Pokharel, (2013). Motherto-daughter communication about menstrual hygiene is an important tool which can enhance healthy reproductive health practices, foster vigorous development and further create a diseasefree reproductive health experience in adulthood. Other adolescents in this study recognized 
the role of sisters, teachers, friends, and relatives in providing information to them about menstrual hygiene and this is supported by the results of a study conducted by Gultie, Hailu, and Workineh (2014) in which teachers were the major sources of information on menstruation.

A large knowledge gap and unmet sexuality education requirement exist for adolescent females when it comes to safe and hygienic menstrual habits. The study revealed that at baseline, the level of female adolescents' knowledge regarding menstrual hygiene was moderate. This study sought to increase the female adolescents' level of knowledge towards menstrual hygiene. The results showed a significant increase in the intervention groups compared with the control group, between the baseline, immediate post-intervention, and 6weeks follow-up. Further exploration revealed that the educational interventional had a positive impact as the level of knowledge was sustained for 6 weeks after the intervention modules had been delivered. The finding is in line with the study conducted by Arora, Mittal, Pathania, Singh, Mehta, and Bunger (2013) and Ogunleye and Kio (2020) on the impact of health education on knowledge and practices about menstruation among adolescent school girls in India and Nigeria respectively.

\section{Implications of the Findings for Health Education}

Health educators can utilize combined interventions that have been proven to be effective in changing human behaviors, as revealed by the findings of this study. Most importantly, peer education has been proven to be more important in improving female adolescents' level of knowledge towards menstrual hygiene.

\section{CONCLUSION}

In conclusion, based on the findings of the study, the peer-led education intervention had the greatest change in the level of adolescents' menstrual hygiene knowledge. This finding implies that despite the information shared by mothers at home, the use of peers in the school setting was effective in impacting better knowledge of menstrual hygiene.

\section{Future Research}

Other researchers may develop interventions for out-of-school female adolescents and mothers on menstrual hygiene, and prevention of reproductive health infections. 


\section{TABLES}

Table 1: Baseline Distribution of Socio-Demographic Characteristics of Respondents in Control and Intervention Groups: Age, Class, and Religion

\begin{tabular}{|c|c|c|c|c|c|}
\hline Variables & $\begin{array}{c}\text { Parent-Led } \\
\text { N }(\%)\end{array}$ & $\begin{array}{c}\text { Peer-Led } \\
\text { N (\%) }\end{array}$ & $\begin{array}{c}\text { Parent- } \\
\text { Led and } \\
\text { Peer-Led } \\
\text { N }(\%)\end{array}$ & $\begin{array}{c}\text { Control } \\
\mathbf{N}(\%)\end{array}$ & $\begin{array}{c}\text { p- } \\
\text { value }\end{array}$ \\
\hline \multicolumn{6}{|l|}{ Age in years } \\
\hline $10-13$ & $9(30.0)$ & $7(23.3)$ & $12(40.0)$ & $5(16.7)$ & \multirow[t]{5}{*}{$0.880^{\mathrm{b}}$} \\
\hline 14-16 & $15(50.0)$ & $20(66.7)$ & $17(56.7)$ & $9(30.0)$ & \\
\hline 17-19 & $6(20.0)$ & $3(10.0)$ & $1(3.3)$ & $16(53.3)$ & \\
\hline Total & $30(100)$ & $30(100)$ & $30(100)$ & $30(100)$ & \\
\hline Mean \pm SD & $14.83 \pm 1.91$ & $14.77 \pm 1.48$ & $13.93 \pm 1.48$ & $16.17 \pm 1.70$ & \\
\hline \multicolumn{6}{|l|}{$\begin{array}{c}\text { Age at } \\
\text { Menarche }\end{array}$} \\
\hline Mean \pm SD & $12.97 \pm 1.47$ & $13.07 \pm 1.70$ & $12.07 \pm 1.17$ & $12.83 \pm 0.87$ & 0.190 \\
\hline \multicolumn{6}{|l|}{ Class } \\
\hline JSS 1 & $7(23.3)$ & $10(33.3)$ & $7(23.3)$ & $6(20.0)$ & \multirow[t]{6}{*}{$0.978^{\mathrm{a}}$} \\
\hline JSS 2 & $7(23.3)$ & $6(20.0)$ & $6(20.0)$ & $10(33.3)$ & \\
\hline JSS 3 & $5(16.7)$ & $5(16.7)$ & $6(20.0)$ & $6(20.0)$ & \\
\hline SSS 1 & $6(20.0)$ & $4(13.3)$ & $6(20.0)$ & $3(10.0)$ & \\
\hline SSS 2 & $5(16.7)$ & $5(16.7)$ & $5(16.7)$ & $5(16.7)$ & \\
\hline Total & $30(100)$ & $30(100)$ & $30(100)$ & $30(100)$ & \\
\hline \multicolumn{6}{|l|}{ Religion } \\
\hline Christianity & $23(76.7)$ & $22(73.3)$ & $20(66.7)$ & $18(60.0)$ & \multirow[t]{4}{*}{$0.431^{\mathrm{a}}$} \\
\hline Islam & $6(20.0)$ & $8(26.7)$ & $10(33.3)$ & $12(40.0)$ & \\
\hline Traditional & $1(3.3)$ & $0(0.0)$ & $0(0.0)$ & $0(0.0)$ & \\
\hline Total & $30(100)$ & $30(100)$ & $30(100)$ & $30(100)$ & \\
\hline
\end{tabular}


Table 2: Baseline Distribution of Socio-Demographic Characteristics of Female Adolescents in Control and Intervention Groups: Ethnic Group, Mother's Level of Education and Mother's Occupation

\begin{tabular}{|c|c|c|c|c|c|}
\hline Variables & $\begin{array}{c}\text { Parent- } \\
\text { Led N } \\
(\%)\end{array}$ & $\begin{array}{l}\text { Peer-Led } \\
\text { N }(\%)\end{array}$ & $\begin{array}{c}\text { Parent-Led } \\
\text { and Peer- } \\
\text { Led } \\
\text { N }(\%)\end{array}$ & $\begin{array}{l}\text { Control } \\
\text { N }(\%)\end{array}$ & p-value \\
\hline \multicolumn{6}{|l|}{ Ethnic Group } \\
\hline Yoruba & $26(86.7)$ & $26(86.7)$ & $24(80.0)$ & $27(90.0)$ & $0.330^{\mathrm{a}}$ \\
\hline Igbo & $0(0.0)$ & $4(13.3)$ & $6(20.0)$ & $1(3.3)$ & \\
\hline Hausa & $1(3.3)$ & $0(0.0)$ & $0(0.0)$ & $2(6.7)$ & \\
\hline Others & $1(3.3)$ & $0(0.0)$ & $0(0.0)$ & & \\
\hline Total & $30(100)$ & $30(100)$ & $30(100)$ & $30(100)$ & \\
\hline \multicolumn{6}{|l|}{$\begin{array}{l}\text { Mother's Level of } \\
\text { Education }\end{array}$} \\
\hline No Formal Education & $8(26.7)$ & $3(10.0)$ & $5(16.7)$ & $6(20.0)$ & $0.553^{\mathrm{a}}$ \\
\hline Primary & $1(3.3)$ & $4(13.3)$ & $0(0.0)$ & $3(10.0)$ & \\
\hline Secondary & $15(50)$ & $14(46.7)$ & $20(66.7)$ & $17(56.7)$ & \\
\hline Tertiary & $6(19.9)$ & $9(30.0)$ & $5(16.7)$ & $4(13.3)$ & \\
\hline Total & $30(100)$ & $30(100)$ & $30(100)$ & $30(100)$ & \\
\hline \multicolumn{6}{|l|}{ Mother's Occupation } \\
\hline Business/Trading & $19(63.3)$ & $24(80.0)$ & $26(86.7)$ & $25(83.3)$ & $0.321^{\mathrm{a}}$ \\
\hline Housewife & $4(13.3)$ & $2(6.7)$ & $1(3.3)$ & $2(6.7)$ & \\
\hline Farmer & $4(13.3)$ & $1(3.3)$ & $2(6.7)$ & $1(3.3)$ & \\
\hline Teacher & $2(6.7)$ & $1(3.3)$ & $1(3.3)$ & $1(3.3)$ & \\
\hline Others & $1(3.3)$ & $2(6.7)$ & $0(0.0)$ & $1(3.3)$ & \\
\hline Total & $30(100)$ & $30(100)$ & $30(100)$ & $30(100)$ & \\
\hline
\end{tabular}


Table 3: Baseline Distribution of Female Adolescents' Menstrual Hygiene Awareness in Control and Intervention Groups

\begin{tabular}{|c|c|c|c|c|c|}
\hline Variables & $\begin{array}{l}\text { Parent-Led } \\
\text { N }(\%)\end{array}$ & $\begin{array}{c}\text { Peer-Led } \\
\text { N }(\%)\end{array}$ & $\begin{array}{c}\text { Parent-Led } \\
\text { and Peer- } \\
\text { Led } \\
\text { N }(\%)\end{array}$ & $\begin{array}{l}\text { Control } \\
\mathbf{N}(\%)\end{array}$ & p-value \\
\hline \multicolumn{6}{|c|}{$\begin{array}{c}\text { Heard about } \\
\text { Menstrual Hygiene? }\end{array}$} \\
\hline Yes & $20(66.7)$ & $21(70.0)$ & $24(80.0)$ & $26(86.7)$ & $0.247^{\mathrm{a}}$ \\
\hline No & $10(33.3)$ & $9(30.0)$ & $6(20.0)$ & $4(13.3)$ & \\
\hline Total & $30(100)$ & $30(100)$ & $30(100)$ & $30(100)$ & \\
\hline \multicolumn{6}{|l|}{$\begin{array}{c}\text { Source of } \\
\text { Menstruation }\end{array}$} \\
\hline Not Informed & $10(33.3)$ & $9(30.0)$ & $6(20.0)$ & $4(13.3)$ & $0.009^{b^{*}}$ \\
\hline Mother & $12(40.0)$ & $6(20.0)$ & $13(43.3)$ & $18(80.0)$ & \\
\hline Sister & $3(10.0)$ & $2(6.7)$ & $3(10.0)$ & $8(26.7)$ & \\
\hline Friends & $0(0.0)$ & $3(10.0)$ & $1(3.3)$ & $0(0.0)$ & \\
\hline Relative & $0(0.0)$ & $2(6.7)$ & $2(6.7)$ & $0(0.0)$ & \\
\hline Teacher & $4(13.3)$ & $8(26.7)$ & $5(16.7)$ & $0(0.0)$ & \\
\hline Media & $1(3.3)$ & $0(0.0)$ & $0(0.0)$ & $0(0.0)$ & \\
\hline Total & $30(100)$ & $30(100)$ & $30(100)$ & $30(100)$ & \\
\hline
\end{tabular}

Table 4: Baseline Comparison of the Level of Female Adolescents' Knowledge of Menstrual Hygiene in Control and Intervention Groups

\begin{tabular}{|c|c|c|c|c|c|}
\hline Variables & $\begin{array}{c}\text { Parent-Led } \\
\text { N (\%) }\end{array}$ & $\begin{array}{c}\text { Peer-Led } \\
\text { N }(\%)\end{array}$ & $\begin{array}{c}\text { Parent-Led } \\
\text { and Peer- } \\
\text { Led } \\
\text { N }(\%)\end{array}$ & $\begin{array}{c}\text { Control } \\
\mathbf{N}(\%)\end{array}$ & p-value \\
\hline
\end{tabular}

Menstruation Hygiene

Knowledge

Poor (0-8.5)

Good (8.51-17)

Total

Mean \pm SD
Measured on a 17-point Rating Scale

${ }^{\mathrm{a}} \mathrm{p}$-value obtained by One-way ANOVA

*significant at $<0.05$ 
Table 5: Comparison of Female Adolescents' Level of Menstrual Hygiene Knowledge at Post-Intervention and 6th-Week Follow Up for Intervention and Control Groups

\begin{tabular}{|c|c|c|c|c|c|}
\hline $\begin{array}{c}\text { Menstrual Hygiene } \\
\text { Knowledge }\end{array}$ & $\begin{array}{l}\text { Parent-Led } \\
\text { N }(\%)\end{array}$ & $\begin{array}{l}\text { Peer-Led } \\
\text { N }(\%)\end{array}$ & $\begin{array}{l}\text { Parent-Led } \\
\text { and Peer- } \\
\text { Led } \\
\text { N }(\%)\end{array}$ & $\begin{array}{l}\text { Control } \\
\text { N }(\%)\end{array}$ & p-value \\
\hline Post Intervention & \multicolumn{4}{|c|}{ Measured on a 17-point Rating Scale } & \\
\hline Poor $(0-4.25)$ & $3(10)$ & $0(0.0)$ & $0(0.0)$ & $14(46.7)$ & \\
\hline Good (17-24) & $27(90)$ & $30(100)$ & $30(100)$ & $16(53.3)$ & 0.000 \\
\hline Total & $30(100)$ & $30(100)$ & $30(100)$ & $30(100)$ & \\
\hline Mean \pm SD & $13.83 \pm 3.17$ & $14.27 \pm 2.02$ & $16.20 \pm 1.22$ & $9.13 \pm 2.22$ & \\
\hline \multicolumn{6}{|l|}{ 6th-Week Follow Up } \\
\hline Poor $(0-4.25)$ & $1(3.3)$ & $0(0.0)$ & $0(0.0)$ & $14(46.7)$ & \\
\hline Good (12.76-17) & $29(96.7)$ & $30(100)$ & $30(100)$ & $16(53.3)$ & 0.000 \\
\hline Total & $30(100)$ & $30(100)$ & $30(100)$ & $30(100)$ & \\
\hline Mean \pm SD & $15.00 \pm 2.27$ & $15.83 \pm 1.09$ & $16.40 \pm 0.93$ & $16.40 \pm 2.31$ & \\
\hline
\end{tabular}

Table 6: Paired T-Test Analysis Showing the Difference in Mean between Female Adolescents' Level of Menstrual Hygiene Knowledge at Baseline and 6thWeek Intervention

\begin{tabular}{|c|c|c|c|c|c|c|c|}
\hline Groups & $\overline{\mathbf{x}}(\mathbf{S E})$ & SD & $\begin{array}{c}\text { Mean } \\
\text { Difference }\end{array}$ & ES (CI) & df & $\mathbf{t}$ & p-value \\
\hline \multicolumn{8}{|c|}{ Parent-Led Intervention Group } \\
\hline Baseline & $8.13(0.45)$ & 2.47 & 6.87 & $\begin{array}{l}2.95(2.36- \\
\quad 3.54)\end{array}$ & 29 & 9.819 & 0.000 \\
\hline $\begin{array}{l}\text { 6th-week Follow-up } \\
\text { Peer-Led Intervention } \\
\text { Group }\end{array}$ & $15.00(0.42)$ & 2.27 & & & & & \\
\hline Baseline & $8.70(0.38)$ & 2.10 & 7.13 & $\begin{array}{l}4.34(3.92- \\
4.75)\end{array}$ & 29 & 19.091 & 0.000 \\
\hline $\begin{array}{l}\text { 6th-week Follow-up } \\
\text { Parent \& Peer-Led } \\
\text { Intervention Group }\end{array}$ & $15.83(0.20)$ & 1.09 & & & & & \\
\hline Baseline & $9.93(0.43)$ & 2.33 & 6.47 & $\begin{array}{l}3.71(3.27- \\
4.15)\end{array}$ & 29 & 12.647 & 0.000 \\
\hline $\begin{array}{l}\text { 6th-week Follow-up } \\
\text { Control Group }\end{array}$ & $16.40(0.17)$ & 0.93 & & & & & \\
\hline Baseline & $8.97(0.41)$ & 2.27 & 0.20 & $\begin{array}{l}0.089(0.481 \\
-0.66)\end{array}$ & 29 & 0.374 & 0.711 \\
\hline 6th-week Follow-up & $9.17(0.42)$ & 2.31 & & & & & \\
\hline
\end{tabular}




\section{Ethical Consideration}

Ethical approval was obtained from Babcock University Health Research and Ethics Committee (BUHREC); the Ministry of Education Planning Research and Statistics, and the Ministry of Health Research Ethics, Ogun State, for ethical approval to conduct the study. Informed consent was sought from all participants before their participation.

\section{Acknowledgement}

Praise and thanks to God Almighty for his showers of blessings, the skills, and the power of the mind to enable me to complete this research work successfully. To my supervisor and study participants, for their support and cooperation in the course of this research. My utmost gratitude to my parents, Sir and Lady S.M. Ekeanyanwu for helping and providing funds for the research work and for their encouragement.

Thank you all.

\section{REFERENCES}

Akinwaare, M. O., Akindele, O. M., \& Oluwatosin, O. A. (2016). Menstrual hygiene practices among adolescents in selected secondary schools around the University of Ibadan, Nigeria. Journal of Medicine and Biomedical Research, 15(1), 92-101.

Alam, M. U., Luby, S. P., Halder, A. K., Islam, K., Opel, A., Shoab, A. K., ... \& Unicomb, L. (2017). Menstrual hygiene management among Bangladeshi adolescent schoolgirls and risk factors affecting school absence: results from a cross-sectional survey. $B M J$ open, 7(7), e015508. http://dx.doi.org/10.1136/bmjopen-2016-015508

Arora, A., Mittal, A., Pathania, D., Singh, J., Mehta, C. \& Bunger, R. (2013). Impact of health education on knowledge and practices about menstruation among adolescent school girls of rural part of district Ambala, Haryana. Indian Journal of Community Health, 25(4); $492-497$

Ball, E. (2017). The Urgent Need to Break Nigeria's Menstruation Taboo. Retrieved from https://www.hart-uk.org/blog/urgent-need-break-nigerias-menstruation-taboo/

Busari, A. O. (2012). Menstrual knowledge and health care behavior among adolescent girls in rural, Nigeria. International Journal of Applied Science and Technology, 2(4), 149154.

Coast, E., Lattof, S. R., \& Strong, J. (2019). Puberty and menstruation knowledge among young adolescents in low-and middle-income countries: a scoping review. International journal of public health, 64(2), 293-304.. https://doi.org/10.1007/s00038-019-01209-0

Deshpande, T. N., Patil, S. S., Gharai, S. B., Patil, S. R., \& Durgawale, P. M. (2018). Menstrual hygiene among adolescent girls-A study from urban slum area. Journal of family medicine and primary care, 7(6), 1439. doi: 10.4103/jfmpc.jfmpc_80_18

Duru, C.O., Ikeanyi, E.M. \& Merenu, I. (2020). Knowledge and practice of menstrual hygiene among adolescent school girls in Umunna, Imo State, Southeast Nigeria: implications for parents, healthcare providers and policy makers. Int J Reprod Contracept Obstet Gynecol. 10(2):458-465.

Edet, O.B., Bassey, P.E.M., Esienumoh, E.E.1. \& Ndep A.O. (2020). An Exploratory Study of Menstruation and Menstrual Hygiene Knowledge Among Adolescents in Urban and 
Rural Secondary Schools in Cross River State, Nigeria. Afr. J. Biomed. Res. Vol. 23 (September, 2020); 321- 326.

Fehintola, F. O., Fehintola, A. O., Aremu, A. O., Idowu, A., Ogunlaja, O. A., \& Ogunlaja, I. P. (2017). Assessment of knowledge, attitude and practice about menstruation and menstrual hygiene among secondary high school girls in Ogbomoso, Oyo state, Nigeria. International Journal of Reproduction, Contraception, Obstetrics and Gynecology, 6(5), 1726- 1732.

Goel, P., Kumar, R., Meena, G. S., \& Garg, S. (2018). Association of sociodemographic characteristics with KAP regarding menstrual hygiene among women in an urban area in Delhi. Tropical Journal of Obstetrics and Gynaecology, 35(2), 158-164.doi: 10.4103/tjog.tjog_58_17

Health for All Initiatives (2019). Menstrual Hygiene Management. Retrived from http://hafai.org/works/menstrual-hygiene-management/

Heidi, D.H. (1986). Menarcheal age in Europe. Yearbook of Phys Anthropol. 1. Vol. 29. 1986. pp. 81-112.

House, S., Mahon, T., \& Cavill, S. (2013). Menstrual hygiene matters: a resource for improving menstrual hygiene around the world. Reproductive Health Matters, 21(41), 257-259.

Huang, H. T., Kuo, Y. M., Wang, S. R., Wang, C. F., \& Tsai, C. H. (2016). Structural factors affecting health examination behavioral intention. International journal of environmental research and public health, 13(4), 395. https://doi.org/10.3390/ijerph13040395

Karapanou, O. \& Papadimitriou, A. (2010). Determinants of menarche. Reproductive biology and endocrinology: $R B \& E, 8,115$. https://doi.org/10.1186/1477-7827-8-115

MacRae, E. R., Clasen, T., Dasmohapatra, M., \& Caruso, B. A. (2019). 'It's like a burden on the head': Redefining adequate menstrual hygiene management throughout women's varied life stages in Odisha, India. PLoS One, 14(8), e0220114. https://doi.org/10.1371/journal.pone.0220114

Mudey, A. B., Kesharwani, N., Mudey, G. A., \& Goyal, R. C. (2010). A cross-sectional study on awareness regarding safe and hygienic practices amongst school going adolescent girls in rural area of Wardha District, India. Global Journal of Health Science, 2(2), 225.

Ogunleye, O.R. \& Kio, J.O. (2020). Nursing Intervention on Knowledge of Menstruation and Menstrual Hygiene Among Adolescents in Irepodun-Ifelodun Local Government of Ekiti State. International Journal of Academic Research in Business, Arts and Science. Volume: 2, Issue: 7 pp 20-30

Okafor-Terver, I.S. \& Chuemchit, M. (2017). Knowledge, belief and practice of menstrual hygiene management among in-school adolescents in Katsina state, Nigeria. J Health Res. 2017;31(Suppl.2): S179-87.

Oniyangi, S. O., \& Oyelami, O. F. (2018). Knowledge and Practices of Menstrual Hygiene among Female Secondary School Students in Iragbiji, Osun State. KIU Journal of Social Sciences, 4(1), 45-53.

Rakhmilla, L. E., Rudibianti, A. R., Biben, V., \& Rosyada, N. A. (2017). Peer education: The effect on menstrual knowledge in early reproductive age women in West Java rural area. Int J Chem Tech Res, 10, 76-83.

Rani, M., Kumari, P., \& Rani, N. (2019). Menstrual practices and knowledge among adolescent girls: A cross-sectional study in rural area of Haryana. Int J Heal Sci Res, 9, $132-7$. 
Sapkota, D., Sharma, D., Pokharel, H. P., Budhathoki, S. S., \& Khanal, V. K. (2013).

Knowledge and practices regarding menstruation among school going adolescents of rural Nepal. Journal of Kathmandu medical college, 2(3), 122-128.

Sharma, N., Shekhawat, R., Gaur, K., Meena, K. K., Meena, G. L., Rathore, M., ... \& Kewalramani, S. (2019). Assessment of knowledge and practice regarding menstrual hygiene among school going adolescent girls of Jaipur city. J Med Sci Clin Res, 7(7), 2808-15.. doi: https://dx.doi.org/10.18535/jmscr/v7i7.108

Thakre, S. B., Thakre, S. S., Reddy, M., Rathi, N., Pathak, K., \& Ughade, S. (2011). Menstrual hygiene: knowledge and practice among adolescent school girls of Saoner, Nagpur district. J Clin Diagn Res, 5(5), 1027-33.

Torondel, B., \& Sumpter, C. (2013). A Systematic Review of the Health and Social Effects of Menstrual Hygiene Management. Retrived from https://www.ncbi.nlm.nih.gov/pmc/articles/PMC3637379 